\title{
Pharmacognostical, Physico-Chemical and Preliminary Phytochemical Analysis of Whole Plant of Piper Longum L.
}

\author{
Fathima Suman $\mathbf{P}^{1}$, Minhaj ${ }^{2}$, I Arthi ${ }^{3}$, Neethu Krishnan $S^{4}$, Riyama Shirin $V K^{5}$ \\ ${ }^{1,3,4,5}$ Department of Pharmacognosy and Phytochemistry, College of Pharmaceutical Sciences, Government \\ Medical College Kannur, Kerala \\ ${ }^{2}$ B Pharm Graduate, Al Shifa College of Pharmacy, Malappuram, Kerala.
}

Corresponding Author: Fathima Suman P

\begin{abstract}
This study deals with the Pharmacognostical physicochemical and phytochemical evaluation of the whole plant of Piper longum L. Pharmacognostical studies include macroscopic, microscopic and physicochemical evaluation. Physicochemical constants showed the values of total ash $(10.8 \%)$, acid insoluble ash $(1.3 \%)$, water soluble ash $(3.2 \%)$, sulphated ash $(12 \%)$, nitrated ash (1.85\%), hot extraction (11.2\%), water soluble extractive (4.8\%), ethanol soluble extractive (12.4\%), ether soluble extractive (5.6\%), loss on drying (29\%), swelling index $(0.33)$ and mucilage content $(0.8 \%)$ w/w. The preliminary phytochemical screening of the alcoholic extract showed presents of alkaloids, phenolic compounds, tannins, mucilage, starch, steroid and flavonoids. This study helps to development of different standard parameters of the plant which help the plant identification and authentication.
\end{abstract}

Key Words: Piper longum L., Whole plant, Pharmacognostic, Phytochemical, Extract

\section{INTRODUCTION}

Medicinal plants have great economic value in the Indian subcontinent. The documentation of conventional knowledge particular at the medicinal uses of plants in the history has provided many important drugs of the modern day. Among historic civilizations, India has been recognised to be rich repository of medicinal plants. The woodland of India is the major repository of large number of aromatic and medicinal plants, raw materials are collected for manufacture of drugs and perfumery products. About 8,000 herbal remedies have been reported and used in AYUSH systems in India. Ayurveda, Unani, Siddha and Folk (tribal) treatments are the major systems of indigenous medicines. Among these systems, Ayurveda and Unani Medicine are most advanced and broadly practised in India. ${ }^{(2)}$

More than seven hundred species are present in the genus Piper they grow in the subtropical and tropical rain forests. Majority of the piper species are used by the indigenous system of medicine in India. ${ }^{(3)}$ Piper longum L. is a small shrub having large root in woody nature, stem is numerous, creeping, jointed that have thickening at the nodes. The leaves are alternate nature, spreading, without stipules and with blades varying greatly in size. The fruits grow as fleshy spikes of $2.5-3.5 \mathrm{~cm}$ long and $5 \mathrm{~mm}$ thickness, are oblong in shape, blunt, and blackish-green in colour. It seen in the hotter parts of India, central Himalayas to Assam, the khasi and the mikir hills, the lower hills of Bengal and the evergreen forests of the Western Ghats from Konkan to Travancore. Its pharmacological actions include antibacterial, hypoglycemic, antispasmodic, cough suppressor, antigiardial, immunostimulatory, 
hepatoprotective, analeptic, antiinflammatory, insecticidal, antimalarial, CNS stimulant, antitubercular, anthelmintic, antinarcotic, antiulcerogenic. ${ }^{(4)}$

\section{MATERIALS AND METHODS Collection and authentication of plant}

Piper longum L. was collected from Malappuram District, Kerala during the month of November, 2020. It was authentified by Dr. P Sreeja, Department of Botany and Research Centre Sir Syed College Taliparamba, Kannur, Kerala. The specimen voucher has been deposited in the Department of Pharmacognosy, College of Pharmaceutical Sciences, Government Medical College, Kannur, Kerala state.

\section{Pharmacognostical studies Macroscopic evaluation}

Macroscopic study was carried out by standard methods to determine the different external characters of stem, leaf and root. The morphological characters of plants include size, shape, colour, odour, taste, appearance which were studied. ${ }^{(5)}$

\section{Microscopic evaluation Transverse section ${ }^{(6)}$}

Microscopic studies were carried out by preparing thin sections of leaf, stem and root of Piper longum L. The fresh or dried parts of the plant were cut into thin sections using a razor blade. Select the thin section of the material. Stain it using phloroglucinol and $\mathrm{HCl}$, wash excess stain with water. First it is observed under compound microscope after staining and mounting and then section is observed with the aid of LeicaM80 Stereo microscope with camera Lucida and documentation system.

\section{Powder microscopy}

The dried parts of the plant were crushed separately to form a powder and then passed through the sieve no.40 to get uniform powder mass. Then the powder was stained with phloroglucinol in presence of hydrochloric acid and the lignified structures were viewed under microscope. ${ }^{(7)}$

\section{Quantitative leaf microscopy \\ Vein- Islet number ${ }^{(8)}$}

Take pieces of leaf lamina with an area of 4 square millimeters from the central portion of the lamina. Clear the pieces by heating in a test tube containing chloral hydrate solution and prepare a mount in glycerol-solution. Place stage micrometer on the microscope stage and examine with $6 \mathrm{x}$ eye piece and $4 \mathrm{x}$ objective. Construct a square using the line, representing 4 square millimeters of area. Place the slide with the cleared leaf piece on the microscope and draw in the veins and veinlets within the square. Count the number of vein-islets within the square including those overlapping on two adjacent sides and excluding those intersected by the other two sides. The obtained result is the number of vein-islets in 4 square millimeters area.

\section{Vein termination number ${ }^{(9)}$}

A piece of the leaf was cleared by boiling in chloral hydrate solution and camera lucida and drawing board were arranged and $1 \mathrm{~mm}$ line was drawn with help of stage mm. A square was constructed on this line in centre of field. Using the slide the number of veinlet termination present within the square was counted and the average number of veinlet termination number from the four square to get the value for 1 square $\mathrm{mm}$ was found as vein termination number.

\section{Stomatal index ${ }^{(8)}$}

Place leaf fragments of about $5 \times 5$ $\mathrm{mm}$ in size in a test tube containing chloral hydrate solution and heat it for about 15 minute. Transfer a fragment to a slide and mount the lower epidermis uppermost and put a small drop of glycerol-ethanol solution on one side of the coverslip to prevent the preparation from drying. Examine with a $6 x$ eye piece and 40x objective to which a microscopical drawing apparatus is attached. Mark on the drawing paper a cross for each epidermal cell and a circle for each stoma. Calculate the result as follows:

Stomatal index $=\frac{S \times 100}{E+S}$ 
Where $\mathrm{S}=$ the number of stomata in a given area of leaf; and

$\mathrm{E}=$ the number of epidermal cells, including trichomes in the same area of leaf.

For each sample of leaf make not fewer than ten determinations and calculate the average index

\section{Physicochemical Parameters ${ }^{(10,11,12)}$ Ash Values}

a) Total ash

About $2 \mathrm{~g}$ of the powdered drug was weighed accurately and spreaded as a fine layer at the bottom of tarred silica crucible. The crucible was incinerated at a temperature not exceeding $450^{\circ} \mathrm{C}$ until free from carbon. The crucible was cooled and weighed. The entire procedure was repeated till a constant weight was observed. The percentage of total ash was calculated with reference to the air-dried drug.

\section{b) Acid insoluble ash}

The ash obtained in the total ash was boiled with $25 \mathrm{ml}$ of hydrochloric acid for 5 minutes. The insoluble ash was collected on an ashless filter paper by filtration and washed with hot water. The insoluble ash was transferred to a tarred silica crucible together with ashless filter paper and ignited at a temperature not exceeding $600^{\circ} \mathrm{C}$, cooled, weighed. The procedure was repeated till a constant weight was observed. The percentage of acid insoluble ash was calculated with reference to the airdried drug.

\section{c) Water soluble ash}

The ash obtained as described in total ash, was boiled with $25 \mathrm{ml}$ of hot water for 5 minutes, filtered on an ashless filter paper and washed with hot water. The insoluble ash was transferred to a tarred silica crucible and ignited at $600^{\circ} \mathrm{C}$. The procedure was repeated to get a constant weight. The weight of the insoluble matter was subtracted from weight of the total ash. The difference in weight was considered for water-soluble ash. The percentage of the water-soluble ash was calculated with reference to the air-dried drug.

\section{d) Sulphated ash ${ }^{(13)}$}

A silica or platinum crucible was heated to redness for 10 minutes, allowed to cool in a desiccator and weighed. 1 to $2 \mathrm{~g}$ of the test drug substance accurately weighed in the crucible was ignited gently at first, until the substance was thoroughly charred. The residue was cooled and moistened with $1 \mathrm{ml}$ of sulphuric acid, heated gently until white fumes no longer evolved and then ignited at $800+25^{\circ} \mathrm{C}$ until all the black particles disappeared. The ignition was conducted in a place protected from air currents. The crucible was allowed to cool and then a few drops of sulphuric acid was added and ignited as before. It was allowed to cool and then weighed. The operation was repeated until two successive weighing did not differ by more than $0.5 \mathrm{mg}$.

\section{e) Nitrated ash:}

A silica or platinum crucible was heated to redness for $10 \mathrm{~min}$ and procedure as mentioned above in the determination of sulphated ash was carried out. Instead of sulphuric acid, here nitric acid was used and rest of procedure was same as mentioned.

\section{2) Extractive Values}

Extractive value is a measure of the content of the drug and its nature.

\section{Cold maceration}

The dried powdered plant was extracted with water, ethanol, petroleum ether and chloroform using the maceration process. The powdered plant material was weighed for about $5 \mathrm{~g}$ and then transferred into a $250 \mathrm{~mL}$ conical flask. The conical flask was filled with different solvents for $100 \mathrm{~mL}$ separately. The flask was kept aside for 24 hours at room temperature with continuous agitation for the first 6 hours, then allowed to stand for 18 hours. The mixtures were then filtered through Whatman filter paper. After that, only 25 $\mathrm{mL}$ of the filtrate was taken and kept above the heating mantle for drying, at a constant 
temperature. The final extractive values were calculated in percentage

\section{a) Hot percolation}

$5 \mathrm{~g}$ of the drug was taken into a conical flask and $100 \mathrm{ml}$ of water was added to it. This mixture was stirred gently and warmed in a water bath for 30 minutes. The solution was shaken gently at intervals. Then the solution was taken from the water bath and cooled and filtered through a cotton plug. $25 \mathrm{ml}$ of the filtrate was taken and evaporated to dryness. The amount of the extract was weighed and multiplied by 4 to get the actual value.

\section{3) Moisture Content}

About $1 \mathrm{~g}$ of drug was taken and powdered. A glass-stoppered bottle was dried for 30 minutes under the same conditions to be employed in the determination and the weight of the bottle was taken. The sample was transferred into the bottle and weight of the bottle with the contents was noted. The sample was distributed evenly and was placed in the drying chamber (Oven). The stopper was removed and left it in the chamber. The drying was carried out by heating to 100 $105^{\circ} \mathrm{C}$. Then, the bottle was removed from the oven and the bottle was closed promptly. The bottle was allowed to cool to room temperature and weighed. The experiment was repeated to get a constant value.

\section{4) Foaming Index}

About $1 \mathrm{~g}$ of the weighed plant material reduced to a coarse powder was transferred to a $500 \mathrm{ml}$ conical flask containing $100 \mathrm{ml}$ of boiling water and boiled moderately for $30 \mathrm{~min}$. Then, it was cooled and filtered into 100-ml volumetric flask and sufficient water was added through the filter to dilute the volume to $100 \mathrm{ml}$. The above decoction was placed into 10 stoppered test tubes (ht. $16 \mathrm{~cm}$, dia. $16 \mathrm{~mm}$ ) in a series of successive portions of $1,2,3$ up to $10 \mathrm{ml}$. The volume of the liquid in each tube was adjusted with water to $10 \mathrm{ml}$. The tubes were stoppered and shaken in a lengthwise motion for 15 seconds of 2 frequencies per second. The tubes were allowed to stand for 15 minutes. The tubes were allowed to stand for $15 \mathrm{~min}$ and the height of the foam was measured.

Calculation:

Foaming Index $=\frac{1000}{a}$

$\mathrm{a}=$ Volume in $\mathrm{ml}$ of decoction used for preparing the dilution in the tube where foaming was observed.

\section{5) Swelling Index}

$1 \mathrm{~g}$ of the drug was transferred to a $100 \mathrm{ml}$ stoppered cylinder containing $90 \mathrm{ml}$ of water. After shaking well for 30 seconds it was allowed to stand for 24 hours, shaking gently on three occasions during this period. Sufficient water was added to produce $100 \mathrm{ml}$. It was mixed gently for 30 seconds and allowed to stand for 5 hours. The final volume was measured. The determination was repeated 3 times.

\section{6) Mucilage Content}

$5 \mathrm{~g}$ of the powdered drug was taken and $100 \mathrm{ml}$ of water added to obtain the aqueous extract of the powder. It was filtered through cotton and the mucilaginous filtrate collected. $10 \mathrm{ml}$ of this mucilage solution was mixed with $25 \mathrm{ml}$ of absolute alcohol to precipitate the mucilage. This mucilage precipitate was collected by filtration with a tared filter paper. The filter paper was dried along with the mucilage. After drying the filter paper was carefully weighed and the mucilage content was calculated from the weight.

\section{$\underset{(10,14)}{\text { Preliminary phytochemical screening }}$}

The coarsely powdered dried whole plant of Piper longum L. was extracted with ethyl alcohol by hot extraction process (Soxhlet) for 4h. After completion of extraction, the solvent was removed by distillation and concentrated. Chemical tests were carried out for extract of Piper longum L. whole plant in order to identify the presence of various phytochemical constituents. 


\section{RESULTS \\ Morphology}

- Stem

Cut pieces of stem having distinct internodes and swollen nodes with a number of small rootlets and root scars; stout, cylindrical shape, 0.2 to $0.6 \mathrm{~cm}$ thickness, aromatic odour, reddish brown to grey colour, pungent taste.

\section{- Leaves}

Leaves are simple, stipulate, alternate and petiolate or nearly sessile. Lower ones broadly ovate, cordate; upper one oblong, ovate, all entire, smooth, thin with reticulate venation, veins are raised beneath of leaf.

\section{- Root}

The roots are long, cylindrical $0.4-$ $0.6 \mathrm{~cm}$ thick. The exterior of the root is reddish brown to muddy, it was longitudinally wrinkled and having roots and root scars on the surface. Aromatic odour, pungent to acrid taste.

\section{- Fruit}

Fruit greenish-black to black, cylindrical in shape, 2.5 to $5 \mathrm{~cm}$ long and 0.4 to $1 \mathrm{~cm}$ thickness, consisting of minute sessile fruits, they arranged around an axis. Surface is rough and composite, broken surface shows a central axis and 6 to 12 fruitlets arranged around an axis. Taste, pungent producing numbness on the tongue. Odour is aromatic.

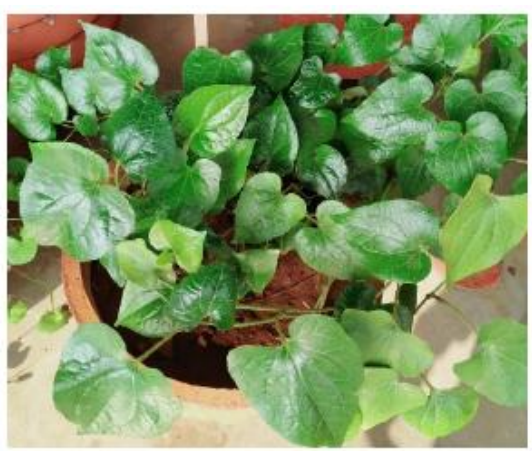

(a)

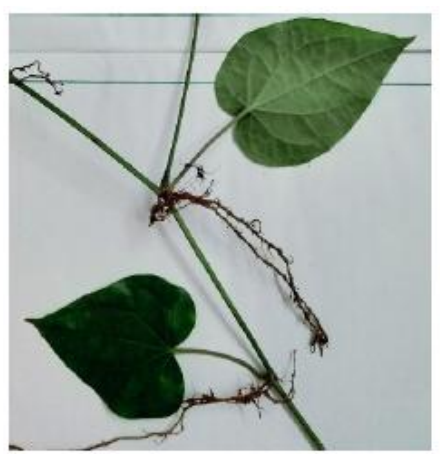

(b)

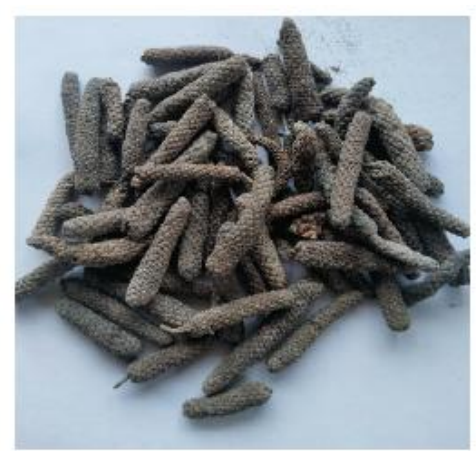

(c)

Fig.1 (a) Piper longum L. Plant (b) Root, leaf and stem of Piper longum L. (c) Dried fruit

\section{Microscopy}

\section{- Transverse section of root}

Transverse section shows outer cork, middle cortex and central stealar region. Transverse section of root is almost circular with the regular outline. The outermost ie. cork appears as a strip which is brown coloured. It consists of 3 to 5 rows of thin walled, rectangular-slightly tangentially elongated cork cells. The cortex is wide and parenchyma except for a small thick -walled cells. The cortical cells are large, thinwalled and rounded to oblong having large intercellular space. Cell walls of the peripheral rows are slightly thickened but not lignified. Most of the cells are heavily loaded with spherical to oval shaped starch grains. Many secretory cells present as scattered in cortex.
Pith is occupied by 4 to 6 wedge shaped radiating strips of vascular tissues (stealar region) having wider ends towards outside. The cells of pith are polygonal, thin walled and have starch grains. Outside the pith, evenly spaced 6 groups of primary xylem bundles are present. In each vascular strip the xylem is composed of xylem vessels and parenchyma surrounded with woody fibres. These xylem vessels arranged in 3 to 4 radial rows. Few thick-walled xylem parenchyma cells are there along with wood fibres.

A strip of cambium consisting one to two rows of narrow thin-walled rectangular cell is present between xylem and phloem. The phloem is composed of many sieve tubes with their companion cells that can be distinctly made out towards the inner region 
of the phloem and small thin-walled polygonal phloem parenchyma cells. The cells at the outer convex side are slightly compressed and appear tangentially elongated. One or two groups of stone cells are present at the peripheral region of the phloem. The outer border of the phloem is limited by a row of pericyclic cells found just inner to the endodermis.

Medullary rays are four to six broad wedges shaped medullar rays with their wider ends at the periphery and alternating with the radiating bands of vascular tissue. Each ray having 10-15 cells in width and extended from pith upto endodermis. The ray cells are all thin walled cubical to slightly radically elongated and arranged in regular radial rows. Most of the cells are heavily loaded with starch grains similar to those present in the cortex. Some cells contain minute crystals of calcium oxalate and a few cells have oil globules.

\section{- Transverse section of stem}

Shows a single layered epidermis of round or oval shaped, followed by a continuous ring of collenchymatous and round to oval thin-walled, parenchymatous cells; vascular bundles show peripheral and medullary arrangement, separated from each other by a wavy strip of sclerenchyma forming a ring, enclosing pith; bundles collateral and arranged in rings, having sclerenchymatous sheath of pericyclic cap over phloem. Xylem wedge-shaped, 2-4 layered, endarch. Phloem is 4-8 layered. Starch grains simple and compound having 2-7 components, round to oval, measuring
3-14 $\mu$ in dia., present abundantly throughout the section. Non glandular unicellular trichomes are present frequently.

\section{- Transverse section of leaf}

The midrib is biconvex, abaxial semi circled with no ridges and furrows, adaxial is angular. Hypodermis is 2 layered in both sides. Transverse section of the dorsiventral leaf shows the presence of single collateral vascular bundle. Stomata is hypostomatic and is cyclocytic. The epidermis of midrib and lamina portion is uniseriate and are covered with thin and smooth cuticle. 2 layered palisade tissues and 3-5 layers of spongy parenchyma with no or small intercellular space is observed. Trichomes are present only in the midrib region of the leaf and are 1-3 cellular glandular trichomes confined only in abaxial surface.

\section{- Transverse section of fruit}

Catkin consist of 6 - 12 fruits, which are arranged like a circle on an axis. Fruits have an outer epidermal layer of irregular cells which are filled with brown content and are covered with a thick cuticle layer. Mesocarp consists of larger cells, collapsed, irregular in shape and thin-walled. Number of stone cells present as singles or as groups. Endocarp and seed coat are fused to a deep zone, outer layer of this is composed of thin-walled cells and is colourless, inner layer is composed of tangentially elongated cells, having reddish- brown content. Most of endocarp filled with starch grains, round to oval measuring 3 - $8 \mu$ diameter.

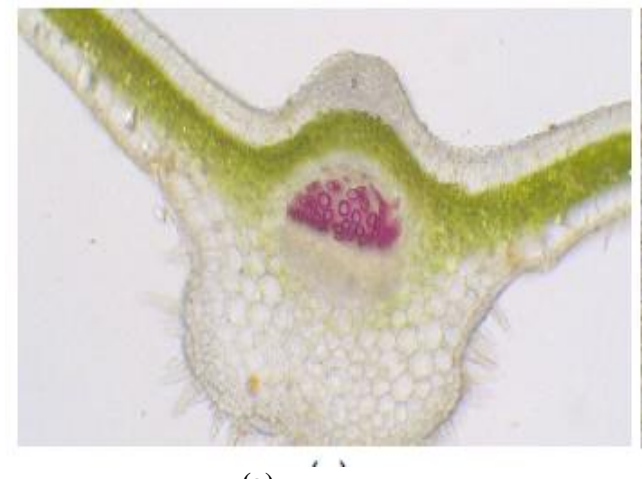

(a)

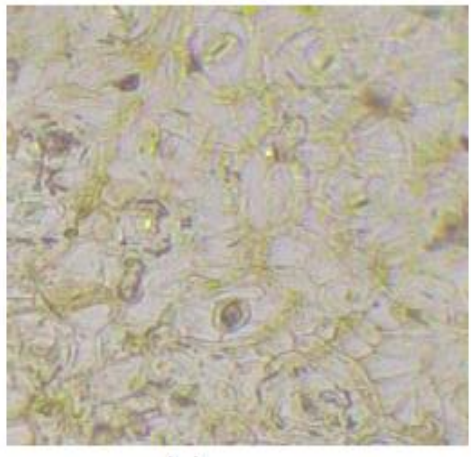

(b)

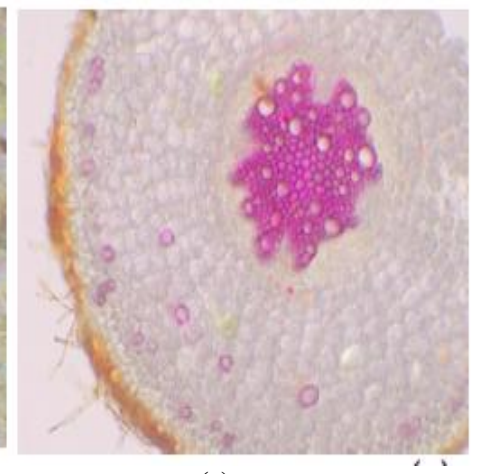

(c) 


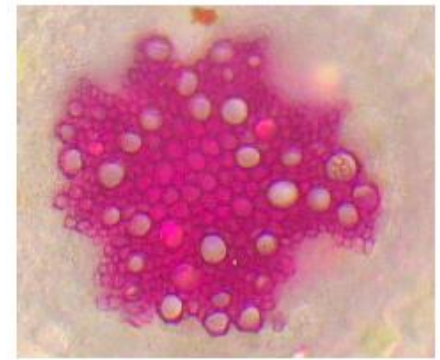

(d)

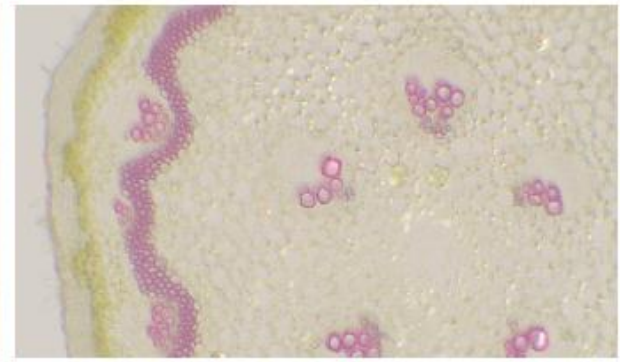

(e)

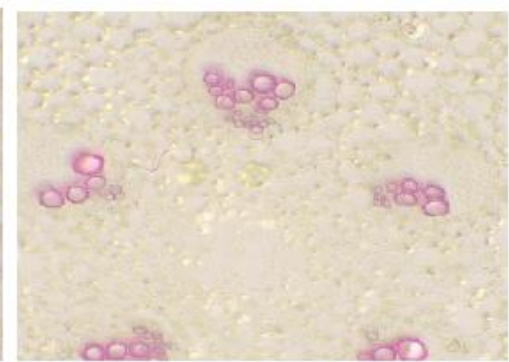

(f)

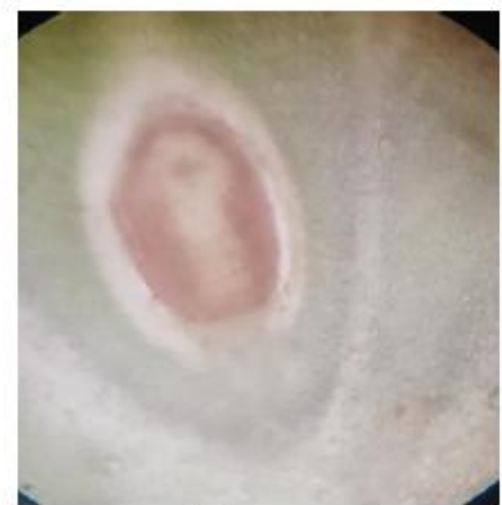

(g)

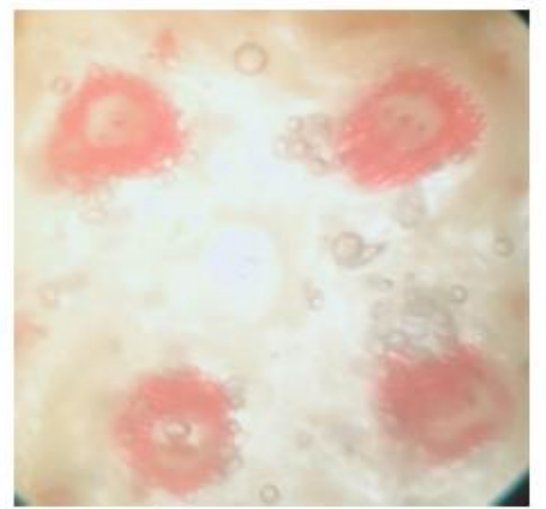

(h)

Fig.2. (a)Transverse section of leaf (b) stomata on the lower side of leaf (c) Transverse section of root (d) Stealar region of root (e) Transverse section of stem (f) Vascular bundles of stem (g) Fruit with endocarp, mesocarp, pericarp and ground tissue (h) Vascular bundle of the fruit.

\section{Powder microscopy}

Stem

Powder is coarse, fibrous, greyish brown coloured with characteristic odour and acrid taste. Powder analysis shows the presence of fibres, xylem vessel, medullary rays and cork cell.

\section{Root}

Powder is coarse, fibrous, brownish white coloured with pungent and characteristic odour. Powder microscopy shows the presence of cork cell, simple and compound starch grains with tannin, pitted vessels, fragments of lignified fibres and sclerides.

\section{Leaf}

The leaf powder of leaf is fine, dark green in colour, fibrous, pungent, heating in taste and with characteristic odour. Powder microscopy shows the presence of unicellular and multicellular trichomes, epidemis with cell wall, parenchymatous cell.

\section{Fruit}

The powder of fruit is dark brown in colour, pungent and heating in taste. The microscopical study of powder shows oval to elongated stone cells, calcium oxalate, brown content and oleo resin.

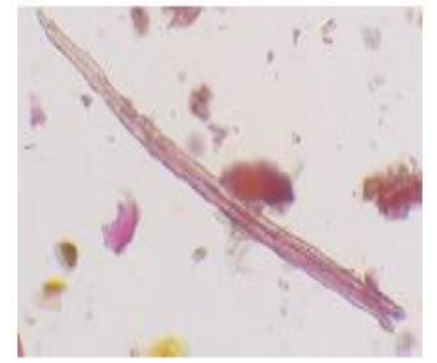

(a)

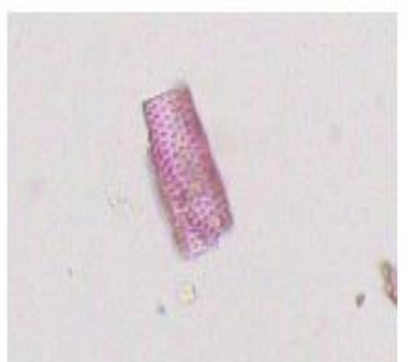

(b)

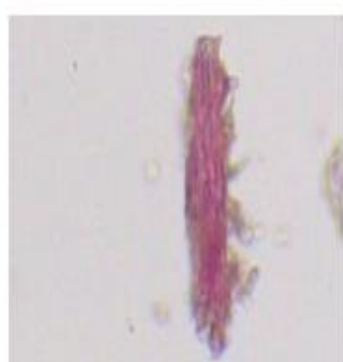

(c)

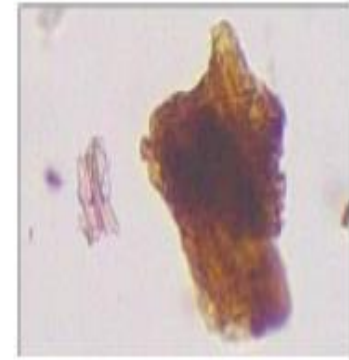

(d)

Fig3. Powder microscopy of stem (a)Fibre (b)Pitted Xylem Vessel (c)Medullary rays(d)Cork cel 
Fathima Suman P et.al. Pharmacognostical, physico-chemical and preliminary phytochemical analysis of whole plant of piper longum $l$.

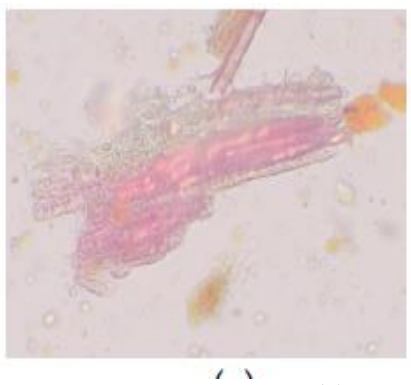

(a)

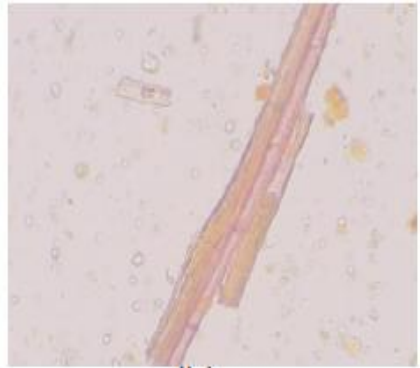

(b)

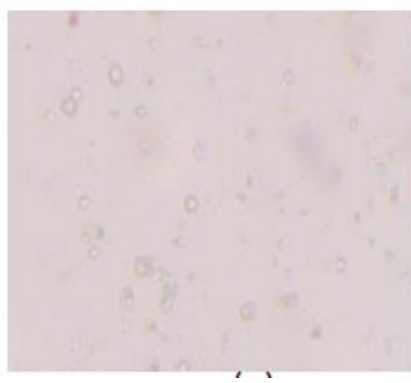

(c)

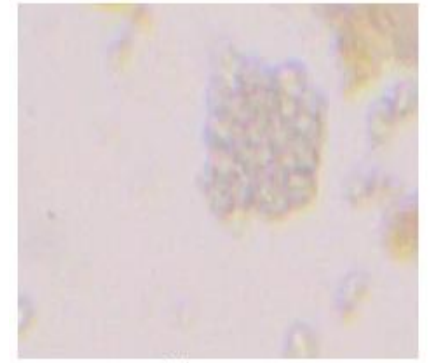

(d)

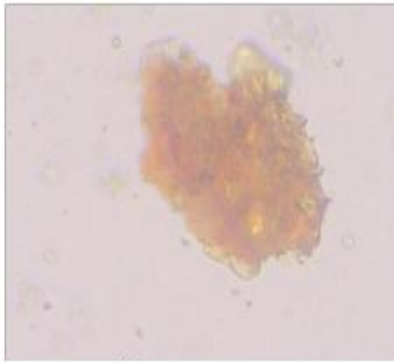

(e)

Fig.4. Powder microscopy of root (a)Scleroids (b)Tracheids and vessels with medullary rays (c)Starch grains (d) Parenchymatous cells with resin (e)Cork

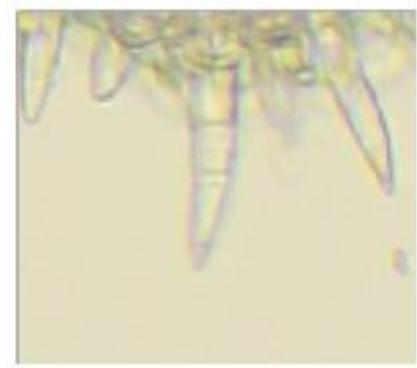

(a)

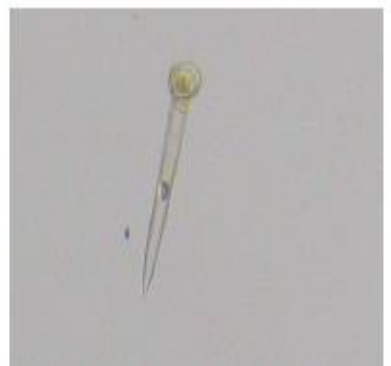

(b)

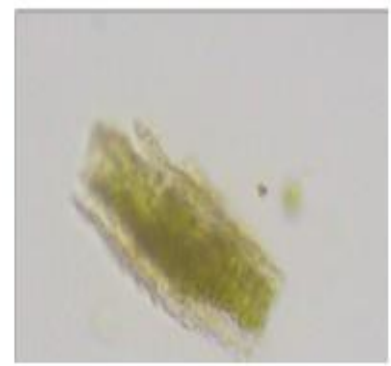

(c)

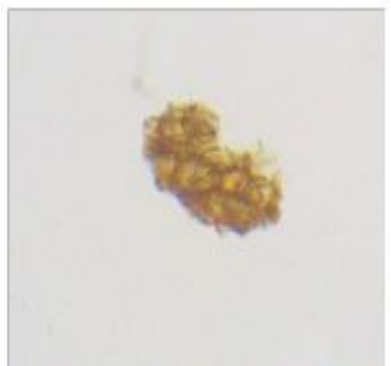

(d)

Fig.5. Powder microscopy of leaf (a)(b) Trichomes (c)Epidermis with cell wall (d)Parenchymatous cell

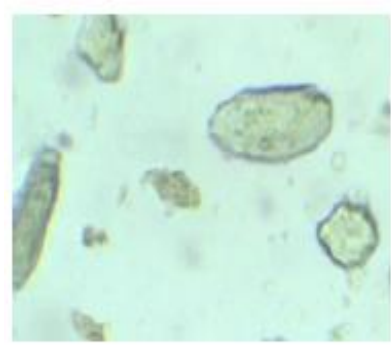

(a)

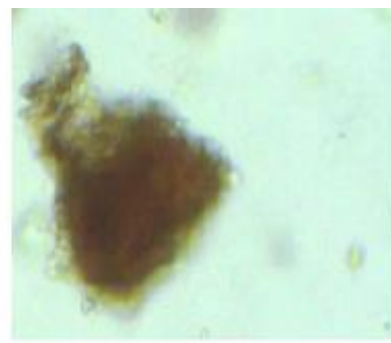

(b)

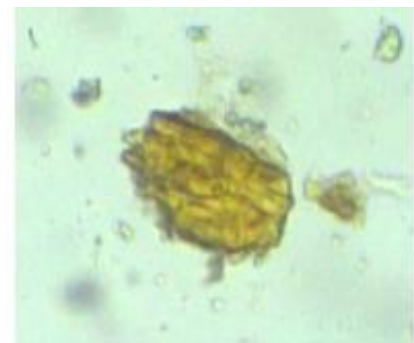

(c)

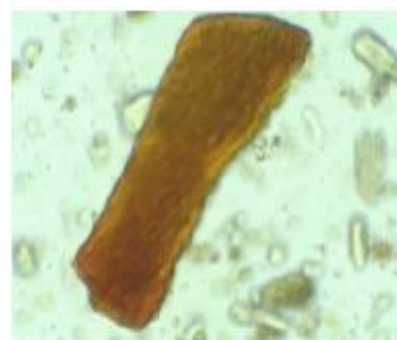

(d)

Fig.6. Powder microscopy of fruit (a) Calcium oxalate (b)Brown content (c) Oleo resin (d)Stone cell

\section{Quantitative leaf microscopy}

The quantitative leaf microscopy of Piper longum L. gives the following constants

Vein islet number -12

Vein termination number -9

Stomatal index -28.1

\section{Physicochemical parameters}

\begin{tabular}{|l|l|}
\hline & Piper longum L. \\
\hline Ash values & \\
\hline (a) Total ash & $10.8 \% \mathrm{w} / \mathrm{w}$ \\
\hline (b) Acid insoluble ash & $1.3 \% \mathrm{w} / \mathrm{w}$ \\
\hline (c) Water soluble ash & $3.2 \% \mathrm{w} / \mathrm{w}$ \\
\hline (d) Sulphated ash & $12 \% \mathrm{w} / \mathrm{w}$ \\
\hline (e) Nitrated ash & $1.85 \% \mathrm{w} / \mathrm{w}$ \\
\hline Extractive values & \\
\hline (a) Hot extraction & $11.2 \% \mathrm{w} / \mathrm{w}$ \\
\hline (b) Water soluble extractive & $4.8 \% \mathrm{w} / \mathrm{w}$ \\
\hline (c) Ethanol soluble extractive & $12.4 \% \mathrm{w} / \mathrm{W}$ \\
\hline (d) Ether soluble extractive & $5.6 \% \mathrm{w} / \mathrm{W}$ \\
\hline Loss on drying & $29 \% \mathrm{w} / \mathrm{w}$ \\
\hline Foaming index & \\
\hline Swelling index & 0.33 \\
\hline Mucilage content & $0.8 \% \mathrm{w} / \mathrm{w}$ \\
\hline
\end{tabular}




\section{Phytochemical screening}

\begin{tabular}{|l|l|}
\hline Test for constituents & Piper longum $\mathbf{L}$. \\
\hline Carbohydrates & - \\
\hline Starch & + \\
\hline Gums & - \\
\hline Mucilage & + \\
\hline Proteins & - \\
\hline Amino Acids & - \\
\hline Fats and Oils & - \\
\hline Steroids & + \\
\hline Glycosides & - \\
\hline Phenolic compounds & + \\
\hline Terpenoids & - \\
\hline Flavanoids & + \\
\hline Alkaloids & + \\
\hline Tannins & + \\
\hline
\end{tabular}

\section{DISCUSSION}

In this study all the important Morphological, microscopic, pharmacognostic and phytochemical properties of different parts of Piper longum L. was characterized by using standard guidelines. The morphological study states that the stem pieces having distinct internodes and swollen nodes with a number of small rootlets and root scars, cylindrical shape with $0.2-0.6 \mathrm{~cm}$ thickness, reddish brown to grey colour, aromatic odour and pungent taste. The leaves are simple, alternate, stipulate, and petiolate or nearly sessile, lower leaves are broadly ovate, cordate, upper one oblong, ovate, all entire, smooth, thin with reticulate venation; veins raised beneath. The roots are long, cylindrical $0.4-0.6 \mathrm{~cm}$ thick. The exterior of the root is reddish brown to muddy, it was longitudinally wrinkled and having roots and root scars on the surface. Aromatic odour, pungent to acrid taste. Transeverse sections of different parts shows the presence of cork, cortex and stealar region (root); vascular bundles, stomata and trichomes (leaf); epidermis, collenchymatous cell, parenchymatous cell and vascular bundles (stem); catkin have fruit inside consist mesocarp and endocarp (fruit).

Powder microscopy revealed the presence various components in the different part of plants like fibre, starch grains, cork cells, calcium oxalate etc (Fig.3, 4, 5, 6). Physicochemical parameter reveals the characters of the plant. Primary phytochemical screening shows the presence major compounds like alkaloids, flavonoids and steroids, which may the reason of majority of the pharmacological action of the plant Piper longum L.

\section{CONCLUSION}

The present study was an attempt to perform the pharmacognostic, phytochemical and physicochemical characterisation of the whole plant of Piper longum L.. The ethanolic extract was used for the phytochemical screening of Piper longum L.. This study helps in the identification and authentication of plants in future studies

Acknowledgement: None

Conflict of Interest: None

\section{Source of Funding: None}

\section{Ethical Approval: Approved}

\section{REFERENCES}

1. Fabricant D.S. Farnsworth N.R. The value of plants used in traditional medicine for drug discovery, Environ. Health Perspect.2001, 109(suppl. 1): 69-75.

2. Jain M, Bhandari A, Bhandari Ankansha, Patel P. Isolation, characterization and invitro Antiurolithiatic activity of cerpegin alkaloid from Ceropegia bulbosa var.lushii root. Int J Drug Dev \& Res 2012; 4(4): 154160.

3. Parthasarathy U, Saji K V, Jayarajan K, Parthasarathy V A; Biodiversity of Piper in South India - application of GIS and cluster analysis. Current Science. 2006; 91(5):652658.

4. Sadhana Singh, Apurva Priyadarshi, Brijesh Singh and Poonam Sharma. Pharmacognostical and phytochemical analysis of Pippali (Piper longum Linn.). The Pharma Innovation Journal 2018; 7(6): 286-289.

5. Abdullahi M N, Ilyas N, Hajara I and Kabir Y M, Pharmacognostic evaluation of the leaf of Microtrichia perotitii DC. (Asteraceae), J Pharmacogn Phytother, 2018, 10(4), 76-84. 

plant of piper longum $l$.

6. Rani S, Gahlaut $\mathrm{K}$ and Kumar $\mathrm{A}$, Pharmacognostical of Cressa cretica linn, study and establishment of quality parameters of whole plant, Der Pharmacia Lettre, 2018, 10(2), 36-51.

7. Srilakshmi P, Determination of physicochemical properties and morphological observation in Syzygium Cumuni leaf galls, Am J Phytomed Clin Ther, 2014, 2, 174-179

8. The Ayurvedic Pharmacopoeia of India. Part-I Volume VI. First edition. Government of India Ministry of Health and Family Welfare Department of AYUSH 2008. PN: 240-242.

9. Dinesh Kumar, Karunesh Kumar and Om Prakash. Pharmacognostic evaluation of leaf and root bark of Holoptelea integrifolia Roxb. Asian Pac J Trop Biomed 2012; 2(3): 169-175.

10. Khandelwal K.R, Practical Pharmacognosytechniques and experiments. Nirali Prakashan, 8th Edition, (2001).
11. Brain K.R., and Turner, T.D., The practical evaluation of phyto pharmaceuticals. Wright Scientechnica, Bristol, 4-35. (1975)

12. World Health Organization Expert Committee, Quality Control Methods for Medicinal Plant Materials, WHO, Geneva. 9, 22-34.

13. Harborne, J.B., In. Phytochemical methodsA guide to modern techniques of plant analysis, 3 Edition, Chapman \& Hall. (1998).

14. Kokate CK., In. Practical Pharmacognosy. Vallabha Prakashan, New Delhi, 107- 103.

How to cite this article: Fathima Suman P, Minhaj, I Arthi. Pharmacognostical, physicochemical and preliminary phytochemical analysis of whole plant of piper longum 1 . International Journal of Research and Review. 2021; 8(8): 440-449. DOI: https://doi.org/10. 52403/ijrr.20210860 